\title{
Identification of differentially expressed transcripts for trunk formation in sago palm using annealing control primer GeneFishing technique
}

\author{
Hasnain Hussain ${ }^{1 *}$ (D), Anastasia Shera Edward-Atit ${ }^{1}$, Norzainizul Julaihi ${ }^{2}$, Rina Tommy ${ }^{2}$, Mehvish Nisar $^{1}$, Nurhazlina \\ Hamdan ${ }^{1}$, Hiroshi Ehara ${ }^{3}$ \\ ${ }^{1}$ Centre for Sago Research, Faculty of Resource Science and Technology, Universiti Malaysia Sarawak, Sarawak, Malaysia. \\ ${ }^{2}$ PELITA Mukah Sebakong Sago Plantation Sdn Bhd, Mukah, Sarawak. \\ ${ }^{3}$ International Center for Research and Education in Agriculture, Nagoya University, Nagoya, Japan.
}

\begin{tabular}{l}
\hline ARTICLE INFO \\
\hline Article history: \\
Received on: March 9. 2021 \\
Accepted on: August 3. 2021 \\
Available Online: February 15, 2022 \\
\hline Key words: \\
Differential display, differentially \\
expressed transcripts (DET), \\
nontrunking, trunking, sago palm
\end{tabular}

\section{INTRODUCTION}

Sago palm is found growing across South East Asia, in the regions of Thailand, Philippines, Indonesia, Malaysia, and Papua New Guinea. The different varieties of the sago palm in the different regions displayed varying degrees in growth duration and starch yield $[1,2]$. The starch formed in the trunk of the sago palm can be harvested and used as a source of carbohydrate and it remains among the highest-yielding starch yield crops in the world [3]. The palm can be found growing in various types of soil, including peat soil. It is estimated that there were 43,448 hectares of land

\footnotetext{
*Corresponding Author

Hasnain Hussain, Centre for Sago Research, Faculty of Resource Science and Technology, Universiti Malaysia Sarawak, Sarawak, Malaysia. E-mail:hhasnain@unimas.my
}

cultivated with sago in Sarawak by smallholder and commercial plantations. The export of sago starch is valued at almost RM62 million in 2019. Japan is one of the largest importers of raw sago starch, estimated to be around 20,000 mt from Malaysia and Indonesia for more than 20 years [4].

Generally, the growth duration of sago palms varies for different varieties of the palm, with some species taking up to 16 years for completion for the trunk-formation stage alone [2,5]. For Metroxylon sagu (Rottb.) palm, the formation of the trunk is generally expected after 4-6 years of planting. However, for a sago palm cultivated in a plantation, there are instances where the trunk failed to form even after 10 years and stay in the rosette stage which can be considered an abnormality. The nontrunking (NT) sago palm has been highlighted as one of the major production limitations [6]. Reasons for this abnormality 
have been discussed in terms of environmental factors $[7,8]$, metabolites [9], and proteomics [5] but none at the genomic and transcriptomic levels.

In earlier studies, the first observations about the affected plants which lead to dwarfism and other such abnormalities often link with nutrient deficiencies and stress tolerance $[5,10]$. It was suggested that nutrient deficiency and various stimuli affected plant growth as an ensuing effect of energy deprivation [11]. Conditions such as drought or flooding, which implicate photosynthesis and respiration, initiate the plant's mechanisms for survival and adaptation by adjusting the growth and development. In the case of sago palm, water shortage and flood affect the palm's growth, possibly causing the extension in growth duration [1]. There is limited research shared in the database about genetic information of the sago palm. The study at the molecular level would help to understand the mechanism or pathway involved in the growth process of the sago palm [12]. A differential display approach will identify the expressed genes, unlike the genome projects. The expressed genes will suggest the possible function leading to specific physiological traits.

In this study, tissue samples from a normal and NT sago palm were differentially expressed using a low-cost Annealing Control Primer (ACP)-based GeneFishing technology and compared for differences in the genetic expression leading to the identification and determination of the genes involved. The use of ACP-based GeneFishing technology is to provide a primer with annealing specificity to the template and allow only targeted products to be amplified [13]. The work described here reports the possibility of the trunk-formation trait of sago palm being controlled by certain gene(s), which can be linked to the expression with possible environmental stimuli. Analyses of the gene expression of the genes will lead to a deeper understanding of the palm's mechanism. By comparing an affected palm with a normal palm, high hopes are placed on discovering the differences in gene expression or any other sign leading to the situation. Thus, the aim of this research work was to compare the expression pattern from trunking $(\mathrm{T})$ and NT sago palms and then isolate the desired bands for identification. The identified transcripts stand as candidate genes responsible for bole or trunk formation.

\section{MATERIALS AND METHODS}

\subsection{Sampling of Plant Materials}

The leaf samples were harvested from matured 14-year-old $\mathrm{T}$ and NT sago palm (Fig. 1) in Pelita Mukah Sebakong Sago Plantation (GPS: 2.851847, 111.827095). The leaf samples were obtained from the third latest developed frond. The leaf samples were harvested in the morning and cut and kept immersed in RNA later (Ambion, USA) solution. Duplicate leaf samples from each plant were obtained for triplicates of T and NT sago palms. In the lab, the samples were removed from the solution and kept at $-80^{\circ} \mathrm{C}$ until further processing.

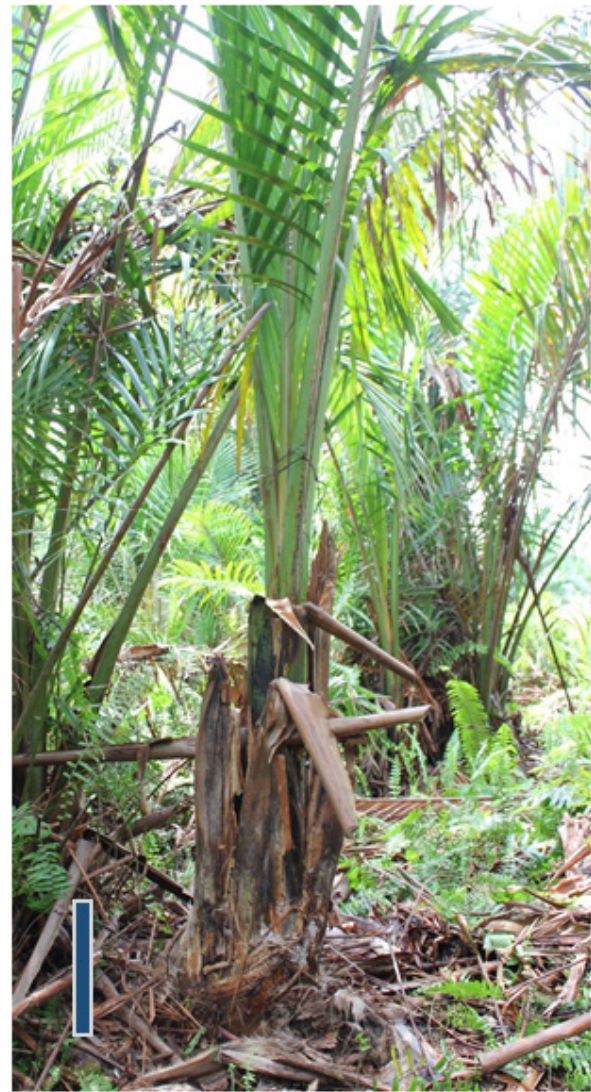

A

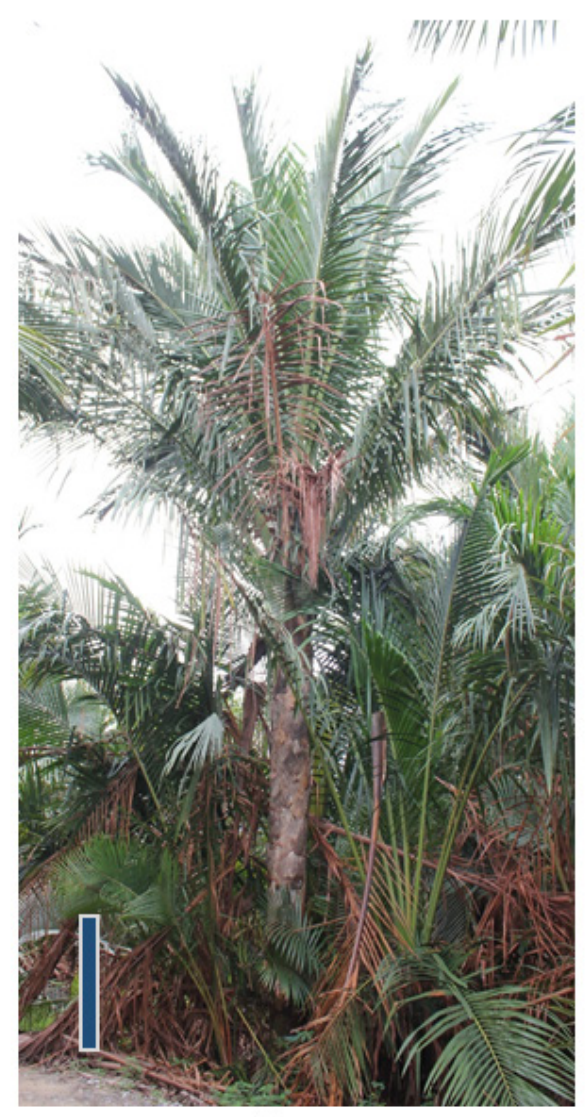

B

Figure 1: (A) NT sago palm; bar equals $0.5 \mathrm{~m}$. (B) T sago palm; bar equals $3 \mathrm{~m}$. 


\subsection{Isolation and Purification of Poly(A) mRNA From Various Plant Tissue Samples}

Leaf tissues were ground into fine powder in the presence of liquid nitrogen. The RNA was extracted from the fine-powdered leaf tissues using extraction kits (RNA queous Total RNA extraction kit, Ambion, USA, and FavorPrep Plant Total RNA Mini extraction kit, Favorgen, Taiwan). Plant Isolation Aid (Ambion, USA) was added to the extraction buffer to counter problems caused by the presence of polysaccharides in tissue samples. The RNA purity was performed through A260/A280 ratio, with the ratio of 1.8 being considered good RNA quality to proceed to the next step.

\subsection{First-Strand cDNA Synthesis and polymerase chain reaction (PCR)}

The amount of poly(A) mRNA isolated was first adjusted to ensure that an equal amount of template from each sample is used in the differential display analysis. Reverse transcription of the poly(A) mRNA was performed using GeneFishing DEG Premix Kit (SeeGene, Korea) and MBiotech (Korea). A reverse transcription reaction includes $10 \mu \mathrm{M}$ dT-ACP1 (5'-CTGTGAATGCTGCGA CTACGATIIIII(T)18-3', with I representing deoxyinosine) and poly(A) mRNA. The reaction was incubated at $80^{\circ} \mathrm{C}$ for 3 minutes and then chilled on ice for 2 minutes and spun briefly. Reagents ( 5 $\times$ RT buffer, $2 \mathrm{mM}$ Deoxynucleoside triphosphate (dNTP), RNase inhibitor, and Moloney-Murine Leukemia Virus (M-MLV) reverse transcriptase) were added to the reverse transcription reaction and incubated at $42^{\circ} \mathrm{C}$ for 90 minutes. The reaction was then heated at $94^{\circ} \mathrm{C}$ for 2 minutes and chilled on ice for 2 minutes and spun briefly and DNase-free water was added to dilute the first-strand cDNA. The first-strand cDNA was stored at $-20^{\circ} \mathrm{C}$ until use.

The first-strand cDNA was used as a template in the subsequent PCR reaction consisting of $10 \mu \mathrm{M}$ dT-ACP2 (5'-CTGTGAA TGCTGCGACTACGATIIIII(T)15-3'), $5 \mu \mathrm{M}$ arbitrary ACP (5'-GTCTACCAGGCATTCGCTTCATIIIII-(10 random sequence)$3^{\prime}$ ) (Table 1), $2 \times$ SeeAmp ACP master mix, and distilled water to a final volume of $20 \mu \mathrm{l}$ volume. The PCR mix was placed in a $94^{\circ} \mathrm{C}$ preheated thermal cycler (Bio-Rad, USA), and the amplification followed the recommended PCR profile. Twenty different arbitrary ACPs provided in the GeneFishing DEG Premix Kit (SeeGene, Seoul, Korea) were used in this study.

\subsection{Selection of Differentially Expressed Transcript (DET)}

The PCR products were separated on $2 \%$ agarose gel and compared for the presence of bands and differences in the intensity between similar-sized bands. The selection of DETs for cloning was done by visual analysis of the transcript pattern on the gel image and the graph and referring to the relative value of band intensity. Images of the transcript were analysed using ImageJ version 1.44 [14], which translates the transcript patterns into graphs, identifying the presence of bands with peaks in the graph. The higher peaks indicated a higher intensity of the bands, while the width of peaks indicated the thickness of the bands. Band sizes among the transcripts were verified by the graph output, which converted the band intensity into a numerical value. The differentially expressed bands showing a similar pattern in the plant triplicates were chosen

Table 1: Arbitrary ACPs sequence used. Provided in the GeneFishing DEG Premix Kit (SeeGene, Seoul, Korea).

\begin{tabular}{cc} 
Arbitrary primers & \multicolumn{1}{c}{ Primer sequence } \\
ACP1 & 5'-GTC TAC CAG GCA TTC GCT TCA TII III GCC ATC GAC C-3' \\
ACP2 & 5'-GTC TAC CAG GCA TTC GCT TCA TII III AGG CGA TGC C-3' \\
ACP3 & 5'-GTC TAC CAG GCA TTC GCT TCA TII III CCG GAG GAT G-3' \\
ACP4 & 5'-GTC TAC CAG GCA TTC GCT TCA TII III GCT GCT CGC G-3' \\
ACP5 & 5'-GTC TAC CAG GCA TTC GCT TCA TII III AGT GCG CTC G-3' \\
ACP6 & 5'-GTC TAC CAG GCA TTC GCT TCA TII III GGC CAC ATC G-3' \\
ACP7 & 5'-GTC TAC CAG GCA TTC GCT TCA TII III CTG CGG ATC G-3' \\
ACP8 & 5'-GTC TAC CAG GCA TTC GCT TCA TII III GGT CAC GGA G-3' \\
ACP9 & 5'-GTC TAC CAG GCA TTC GCT TCA TII III GAT GCC GCT G-3' \\
ACP10 & 5'-GTC TAC CAG GCA TTC GCT TCA TII III TGG TCG TGC C-3' \\
ACP11 & 5'-GTC TAC CAG GCA TTC GCT TCA TII III CTG CAG GAC C-3' \\
ACP12 & 5'-GTC TAC CAG GCA TTC GCT TCA TII III ACC GTG GAC G-3' \\
ACP13 & 5'-GTC TAC CAG GCA TTC GCT TCA TII III GCT TCA CCG C-3' \\
ACP14 & 5'-GTC TAC CAG GCA TTC GCT TCA TII III GCA AGT CGG C-3' \\
ACP15 & 5'-GTC TAC CAG GCA TTC GCT TCA TII III CCA CCG TGT G-3' \\
ACP16 & 5'-GTC TAC CAG GCA TTC GCT TCA TII III GTC GAC GGT G-3' \\
ACP17 & 5'-GTC TAC CAG GCA TTC GCT TCA TII III CAA GCC CAC G-3' \\
ACP18 & 5'-GTC TAC CAG GCA TTC GCT TCA TII III CGG AGC ATC C-3' \\
ACP19 & 5'-GTC TAC CAG GCA TTC GCT TCA TII III CTC TGC GAG C-3' \\
ACP20 & 5'-GTC TAC CAG GCA TTC GCT TCA TII III GAC GTT GGC G-3' \\
\hline
\end{tabular}

Bold represents different nucleotide sequences for ACP primers. 
and recovered using the GF-1 Gel DNA recovery kit (Vivantis, Malaysia) following the manufacturer's protocol.

\subsection{Cloning of DETs}

The DETs recovered were ligated into a pGEM-T easy cloning vector (Promega, USA). The ligation mix was added to $50 \mu \mathrm{l}$ of competent cells (JM109 or XL-1Blue) and transformed using the heat-shock method. Preliminary screening of colonies for successful transformants was done by the blue/white screening method. Upon confirmation of successful clones, plasmid extraction using the alkaline lysis method was carried out on 1.5 $\mathrm{ml}$ of fresh overnight culture cell pellet. The resulting plasmid DNA pellet was dissolved in $50 \mu \mathrm{l}$ of $\mathrm{dH}_{2} \mathrm{O}$ and an aliquot of the clones was sequenced based on the dideoxy sequencing method.

\subsection{Analysis and Characterization of DETs}

The sequencing results of the DETs were checked for reliability by checking the chromatogram and performing alignment between the forward and reverse sequences using the ClustalW [15]. Before a BLAST search for sequence alignment, the sequences were screened for vector sequences using the online VecScreen program (http://www.ncbi.nlm.nih.gov/VecScreen/VecScreen. html). Further removal of sequences from dt-ACP2 and the respective arbitrary primer was then performed manually. Further analysis included searching the screened sequences for open reading frames using the search tool Open Reading Frame (ORF) Finder (http://www.ncbi.nlm.nih.gov/gorf/gorf.html) and the standalone software CLC Sequence Viewer version 6 (CLC Bio). The outcome of the search was translated into protein sequence and searched against the online database for similarity using the BLASTP search tool (http://blast.ncbi.nlm.nih.gov/blastp.cgi).

\section{RESULTS AND DISCUSSION}

\subsection{Differential Expression Analyses}

The transcript patterns for the PCR products separated on a $2 \%$ agarose gel showed some differentially expressed bands with sizes ranging between 100 and $900 \mathrm{bp}$. Five DETs selected for their presence in either one sample had over $92 \%$ difference in the intensity values between NT and T. Out of these, two contained unannotated sequence. Seven DETs with a clear difference in band intensity had $55 \%$ to over $200 \%$ difference in intensity values between $\mathrm{T}$ and NT. The remaining 11 DETs had a range of $16 \%$ $127 \%$ difference in intensity between T and NT, and a further two DETs had $4 \%$ and $9 \%$ difference. The bands that appear more reproducible in the different batches of amplification were desired. Excision was difficult for closely situated bands and priority was placed on the larger sized DETs of over $300 \mathrm{bp}$. When the cloned sequences were cleaned up by the removal of vector sequence as well as the tagging sequence from the GeneFishing primers, the real sequences were about $100 \mathrm{bp}$ less than the size indicated during gel electrophoresis. Examples of differently expressed bands and their relative intensity values are shown in Figures 2 and 3. Bands that were differentially expressed in $\mathrm{T}$ and NT are summarized in Table 2.

A low restriction search on the successfully cloned transcripts found multiple ORFs within a stretch of the DET sequence. Some other sequences did not contain an ORF. The results were double-checked using the standalone software, CLC Sequence
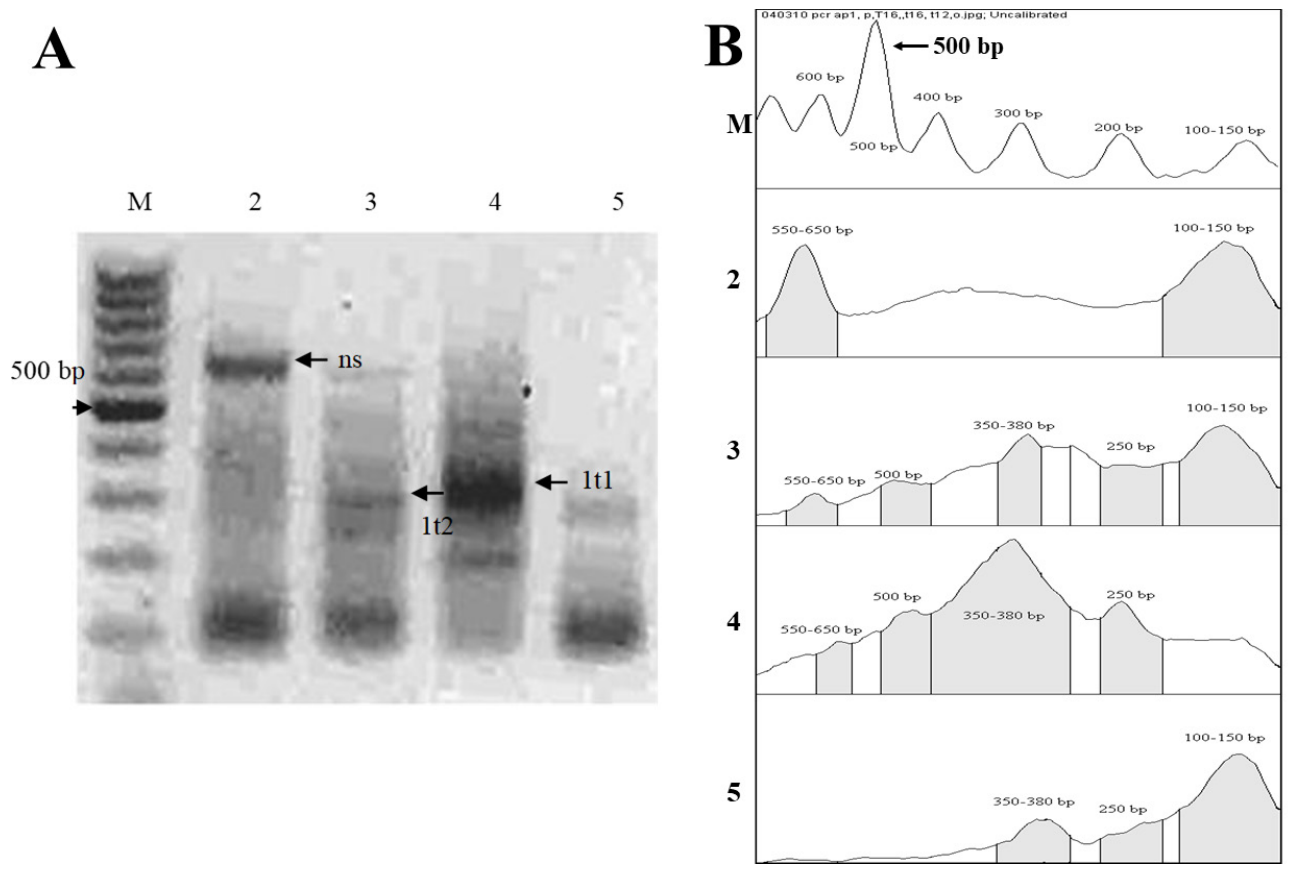

Figure 2: Transcript pattern for amplification with ACP1. (A) Gel photos. Lanes: M, 100 bp marker; 2, NT sample; 3 and 4, T sample; 5, rosette sample. (B) Graphic representation of ACP1 transcripts. Graphs represent transcripts in the respective lanes. The arrows indicate bands that show differences between T and NT; $1 \mathrm{t} 1$ and $1 \mathrm{t} 2$ DETs were selected and excised for identification. The unselected DET is labeled as ns. 
Table 2: Differences in DETs' intensity value between T and NT sample (\%).

\begin{tabular}{|c|c|c|c|c|c|c|}
\hline $\begin{array}{l}\text { DET } \\
\text { label }\end{array}$ & $\begin{array}{l}\text { DET size } \\
\text { estimate } \\
\text { (bp) }\end{array}$ & $\begin{array}{l}\text { Relative } \\
\text { T }\end{array}$ & $\begin{array}{l}\text { Inscript i } \\
\text { NT }\end{array}$ & $\begin{array}{l}\text { nsity value } \\
\text { T-NT }\end{array}$ & $\begin{array}{l}\text { Intensity difference }^{\mathrm{a}} \\
\qquad(\%)\end{array}$ & $\begin{array}{l}\text { Translated protein sequence }{ }^{\mathrm{b}} \text { remarks and identity } \\
\qquad \% \text { similarity; } e \text {-value; species }\end{array}$ \\
\hline $1 \mathrm{~T} 2$ & 300 & 26,477 & 17,099 & 9,378 & 35.42 & $\begin{array}{l}\text { MPLDARIKLDWLMQKKKK } \\
\text { ID: cobalt transport protein, } \mathrm{CbiO} \\
82 \% ; 2.6 ; \text { Arthrospira platensis str. Paraca }\end{array}$ \\
\hline $1 \mathrm{~T} 1$ & $350-380$ & 9,279 & 7,658 & 1,621 & 17.47 & $\begin{array}{l}\text { NTRVSASKTYSVNEVTITDTEPR } \\
\text { ID: S-locus-specific glycoprotein (SLG) S13 precursor } \\
85 \% \text {; 0.74; Ricinus communis }\end{array}$ \\
\hline $2 \mathrm{~T} 1$ & $320-350$ & 6,987 & 3,889 & 3,098 & 44.34 & $\begin{array}{l}\text { LGPTNNRSFQVLRHKSRQVGNQAYRSLFH } \\
\text { ID: zinc-finger, DBF-type containing } 2 \\
59 \% ; 10 ; \text { Oryctolagus cuniculus }\end{array}$ \\
\hline $4 \mathrm{NT} 3$ & $350-400$ & 8,526 & 12,535 & $-4,009$ & -47.02 & $\begin{array}{c}\text { MSNECSTWVCLSTSSGRKWFDVMG } \\
\text { ID: riboflavin synthase, subunit alpha; } \mathrm{Ca}^{2+} / \mathrm{Na}^{+} \text {antiporter } \\
\text { Reinekea sp. Strain designation for Reinekea blandensis } 297 \text { (MED297) }\end{array}$ \\
\hline $4 \mathrm{NT} 2$ & 400 & 16,914 & 37,770 & $-20,856$ & -123.31 & $\begin{array}{c}\text { MFVTLGDERCTLEDCRRMIGVVDSNGDGFV } \\
\text { RFEDFVRMMHGDGTNLGI } \\
\text { High-intensity difference } \\
\text { ID: calmodulin; membrane-associated zinc metallopeptidase }\end{array}$ \\
\hline $5 \mathrm{~T} 1$ & $600-700$ & 29,167 & 10,197 & 18,970 & 65.04 & $\begin{array}{c}\text { WQVTDPNKIFCFLFVWGDRTGVVLFPGFSPFWCLLFPPLRLFVC } \\
\text { NHLDRIIYHQSSTYDKEGSEESAPVAIVNPSREFKASRA } \\
\text { High-intensity difference }\end{array}$ \\
\hline $8 \mathrm{~T} 1$ & $800-900$ & 7,545 & 2,569 & 4,976 & 65.95 & $\begin{array}{c}\text { NNG(LDIAVRLLEPIKEQFPILTYADFYQLAGVVAVEITGGPEIPFHPG } \\
\text { REDKPEPPEEGRLPDATKG(SDHLRDVFGH)MGLSDQDIVALSGGH } \\
\text { TLGRCHKERSGFEGAWTSRPLIFDNSYFTELLTGEKEGLLQLPSDKA } \\
\text { LLSDPVFRPLVEKYADDEDAFFADYVEAHLKLSELGFAEA } \\
\text { High-intensity difference } \\
\text { ID: cytosolic APX; glucosyltransferase } \\
\text { family 2; DHS }\end{array}$ \\
\hline 9NT2 & 400 & 4,943 & 31,102 & $-26,159$ & -529.21 & $\begin{array}{c}\text { MERGYFCYRGRALRPRHV } \\
\text { High-intensity difference in NT } \\
\text { ID: MAPK4 }\end{array}$ \\
\hline $11 \mathrm{NT} 1$ & 350 & 2,620 & 5,935 & $-3,315$ & -126.53 & $\begin{array}{l}\text { MMEICPSHQTPLGVNKLSHD; LDKANNIFNYRKKKKKKK } \\
\text { ID: transcriptional regulator GntR family with aminotransferase domain; } \\
\text { ER-Golgi soluble N-ethylmale-imide-sensitive factor-attachment protein } \\
\text { receptors (SNARE) complex subunit }\end{array}$ \\
\hline $11 \mathrm{~T} 1$ & 650 & 4,352 & 2,208 & 2,144 & 49.26 & $\begin{array}{l}\text { DKTKTDAGYPAGIGVKNS(LFVLAGCNLLGLLFTFLVPESKG } \\
\text { KSLEE(MSGENEEEDLTETSYSRTVPV; FAKNWQPGCLICPIYIKL } \\
\text { ID: inorganic PHT3; Crp/Fnr family transcriptional regulator }\end{array}$ \\
\hline $14 \mathrm{~T} 3$ & 300 & 12,481 & 11,737 & 744 & 5.96 & $\begin{array}{l}\text { SLKVFQRLATGESKNNTKTREPK } \\
\text { ID: beta-glucosidase }\end{array}$ \\
\hline $14 \mathrm{~T} 1$ & 380 & 9,695 & 6,229 & 3,466 & 35.75 & $\begin{array}{l}\text { MILNKFKLERDIVFSFFFPSVYIIF } \\
\text { ID: O-antigen ligase-like protein }\end{array}$ \\
\hline & & & & & & $\begin{array}{l}\text { (IDEIAQEYAGRIKCYKINTDDYPQVATSHNIDRIPTV(LLFKDGE)ML } \\
\text { KSMTGTLPKSVYVTAIEKSLSH; MLLSISPSLNSNTVGIRSML; } \\
\text { LCFTNQCHTALFSFNTV }\end{array}$ \\
\hline $15 \mathrm{NT} 1$ & $500-550$ & 3,806 & 8,206 & $-4,400$ & -115.61 & Clear intensity difference; \\
\hline & & & & & & $\begin{array}{l}\text { ID: thioredoxin m3; NADH-dehydrogenase subunit 2; Guanosine guanosine } \\
\text { triphosphatease activating protein; UDP-N-acetylmuramoyl-L-alanyl-D- } \\
\text { glutamate-lysine ligase }\end{array}$ \\
\hline $17 \mathrm{~T} 1$ & $300-320$ & 41,360 & 17,852 & 23,508 & 56.84 & $\begin{array}{l}\text { MFQGRTLFNLNTLQALDPKP } \\
\text { Clear intensity difference; } \\
\text { ID: glycerol kinase }\end{array}$ \\
\hline $19 \mathrm{~T} 5$ & $500-600$ & 16,788 & 9,153 & 7,635 & 45.48 & $\begin{array}{c}\text { MQLMTDNRIRHIPVIEDKGMVGMVSIGD } \\
\text { VVRAVVTEHREELDRLNAYIQGGY; } \\
\text { MLKYWGELFYCQTLFAIIIELYWNRLALVATLYVSIEAVQ } \\
\text { LLAMLSHHSSNNIPDGDHADHTLVFNHWNVSDTIICHKLH }\end{array}$ \\
\hline & & & & & & $\begin{array}{l}\text { ID: CBS domain-containing protein; peptide- } 2 \mathrm{ABC} \text { transporter, adenosine } \\
\text { triphosphate (ATP)-binding/membrane-spanning protein }\end{array}$ \\
\hline
\end{tabular}

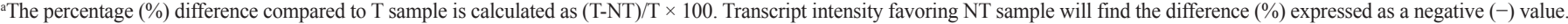

${ }^{\mathrm{b}} \mathrm{The}$ sequences that differentiate between the ORFs are marked in parentheses.
} 

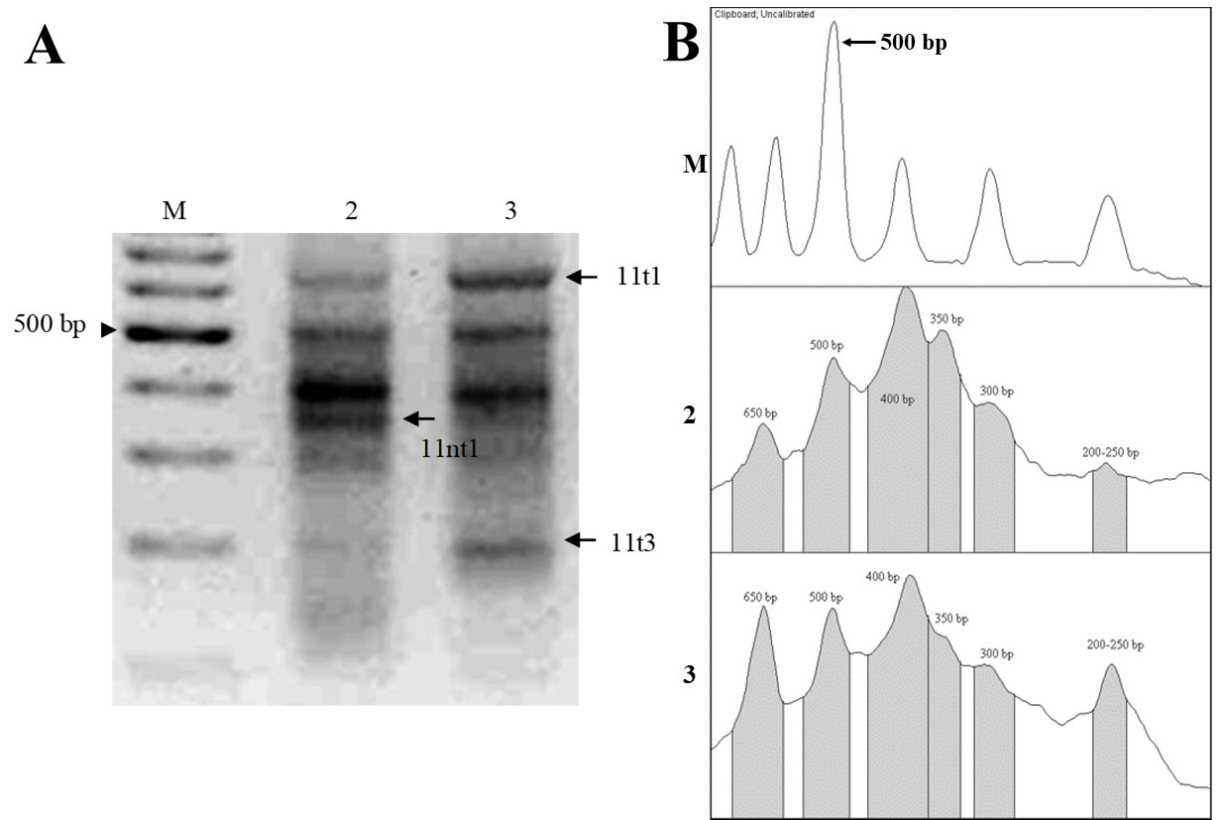

Figure 3: Transcript pattern for amplification with ACP11. (A) Gel photos. Lanes: M, 100 bp marker; 2, NT sample; 3, T sample. (B) Graphic representation of ACP11 transcripts. Graphs represent transcripts in the lanes. The arrows indicate bands that show differences between T and NT; 11nt1, 11t1, and 11t3 DETs were selected and excised for identification.

Viewer. These ORFs amounted to 185 sequences, annotated and unannotated. The ORF sequences were aligned to the online database using BLASTP. The list of ORF sequences identified in the DETs and the resulting identity matches are presented in Table 2. The ORFs are listed with details such as the location of sequence and length in amino acids (aa), while the alignment details are accompanied by a max score and an expectation value (e-value) to indicate the significance of the match. A high max score and low $e$-value present higher reliability of the sequence match.

The 43 annotated sequences made up a functionally diverse group of proteins and enzymes, with roles such as redox regulators and roles in biosynthesis and plant defense mechanism, among others. Table 2 shows a compilation of the identity matches for the ORF, which will be discussed about the calculated differential expression. ORF sequences that lack similarity to the sequences in the database, matching nonannotated proteins and with lowsimilarity matches, present the possibility of being novel genes.

\subsection{Functional Analyses of DETs}

DET profiles showed the gene expression of $\mathrm{T}$ and NT sago palm leaves. Comparison of different profiles would allow the determination of potential genes responsible for trunk formation in the sago palm. This provides baseline information about the molecular studies of the sago palm while imparting future researchers with a list of target sequences for further works of annotating possible novel genes and other proteomic studies. The DETs with identity matches were results of amplification using ACP $1,2,4,5,8,9,10,11,13,14,15,17$, and 19. Examples of the DET profiles are shown in Figure 4. The different ORF sequences in a single DET also presented identity matches with a variety of protein functions. These include functions in regulating metabolic pathways, in the intercellular and intracellular signaling and transport of molecules, and in catalyzing various biosynthetic reactions in studied organisms ranging from prokaryotes to eukaryotes. However, only identities with known presence in plants are included in the discussion.

\subsection{DETs with Redox-Related Functions}

Compounds such as reactive oxygen species (ROS) and free radicals are present in all living organisms. Along with other electron-related species, these compounds act as messengers via redox signaling. The high presence of ROS in some parts of the cell, such as in mitochondria, can be attributed to roles carried by the organelles involved, and these by-products of respiration reactions are harmful when accumulated. Linked to its regulation and other redox signaling roles are the following identified DETs.

The DETs encoding for short-chain dehydrogenase/reductase (SDR) and Crp/Fnr family transcriptional regulator were both higher in the $\mathrm{T}$ sample by $47 \%$ and $49 \%$, respectively. Both proteins are functionally versatile due to their structures. The SDRsuperfamily (SDR) is a group of oxidoreductases that are Nicotinamide Adenine Dinucleotide (Phosphate) (Reduced) Nicotinamide Adenine Dinucleotide (Phosphate) (Reduced) $(\mathrm{NAD}(\mathrm{P})(\mathrm{H}))$-dependent. The characteristic Rossmann fold of the SDR protein structure enables it to act as scaffolds for various binding activities of $\operatorname{NAD}(\mathrm{P})(\mathrm{H})$ [16]. SDR is often expressed during development at certain stages in specific tissues, for example, tuber, glandular hair of leaves, roots, flowers, and fruits $[16,17]$. Owing to the conserved motifs in the enzyme, SDR proteins are involved in the redox sensor system, which is linked to regulating the metabolism of amino acid, carbohydrate, cofactor, hormone, lipid, and xenobiotic, as well as in the transcription and signaling. The protein $\mathrm{Crp} / \mathrm{Fnr}$ 

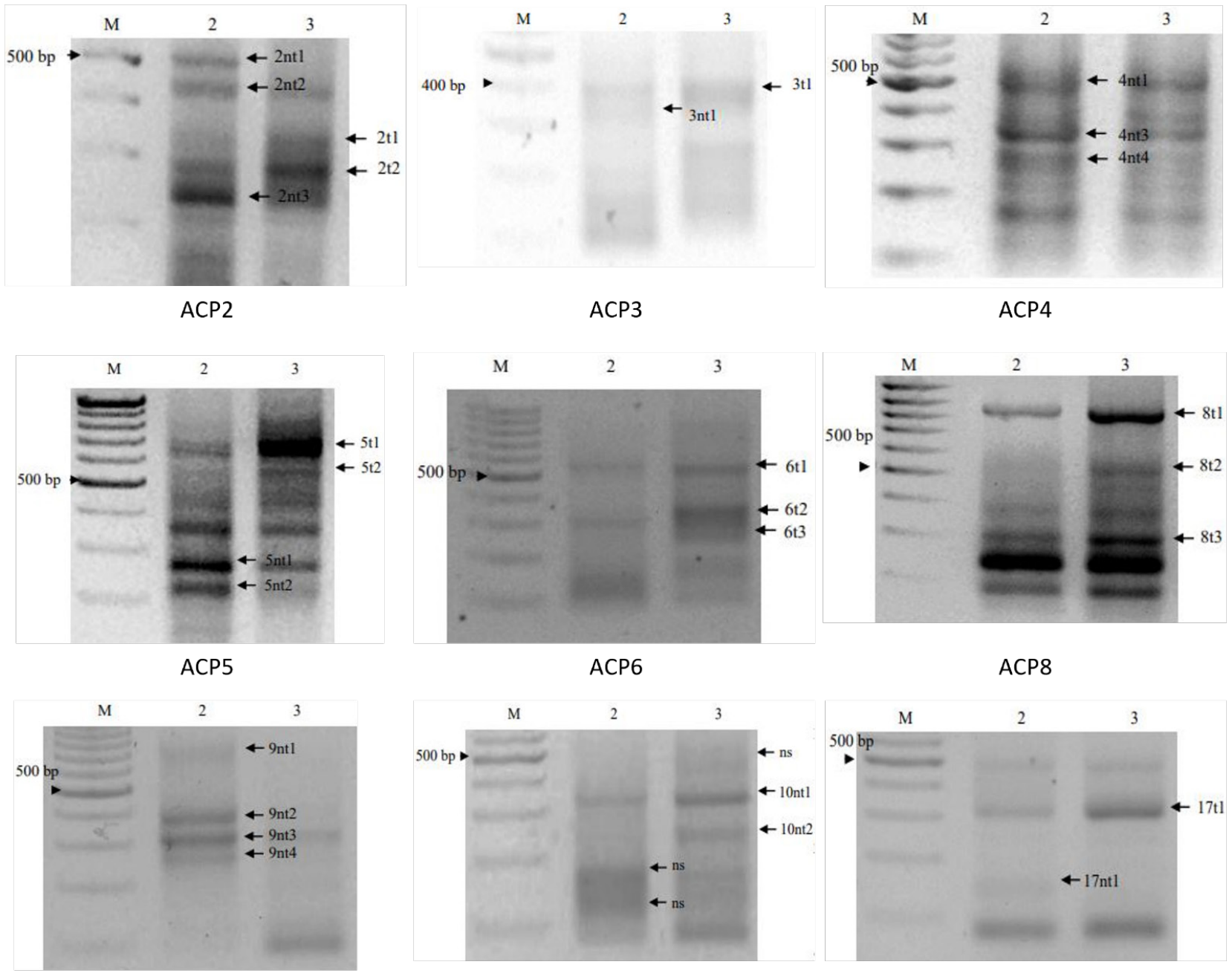

ACP9

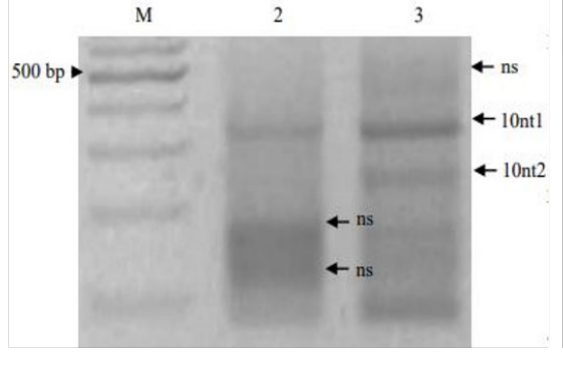

ACP10

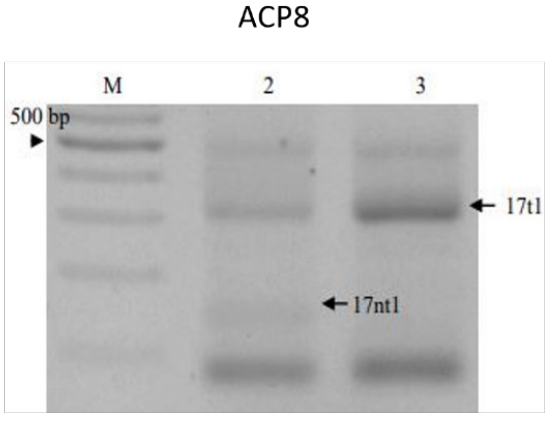

ACP17

Figure 4: Transcript pattern for amplification with ACP2, ACP3, APC4, ACP5, ACP6, ACP8, ACP9, ACP10, and ACP17. Lanes: M, 100 bp marker; 2, NT sample; 3, T sample.

transcriptional regulators belong to a large family characterized by an amino-terminal cyclic nucleotide-binding $\left[\mathrm{c}^{\prime}\right.$ nucleotide monophosphate] domain followed by a specific DNA-binding domain comprised of helix-to-helix motif [18]. The protein Crp/Fnr family of transcriptional regulator functions in the areas of sensory mechanism, DNA recognition, and RNA polymerase interaction [19] and response to various signals, intracellular and exogenous, to include cAMP, anoxia, redox state, oxidative stress, and nitrosative stress [18].

Ascorbate peroxidase (APX) is a redox-regulating protein that uses the ascorbate group to reduce peroxide, a species of ROS, to water. The transcript for cytosolic APX was found with a higher abundance in T samples (81\%). In other studies, a few types of APXs accumulate in stress-induced plants [20,21]. APX activity was also reported to upregulate in response to heavy metal, drought, water, and heat stress $[22,23]$. The cytosolic APX specified the expression in cytosols. Out of the few types identified, the cytosolic APX was recommended to be involved in combination stresses. While the APXs may seem readily present in nonstressed plants, this is probably due to the differences in roles played by the APX types.

Accompanying various redox reactions are the electron acceptors and oxidoreductases. The DET encoding for both NADHdehydrogenase subunit 2 and thioredoxin $m_{3}$ [Thioredoxin (TRX) $-\mathrm{m}_{3}$ ] was found to be more abundantly expressed in NT (116\%). NADH-dehydrogenase subunit 2 is one of the many subunits making up the proton-pumping NADH-dehydrogenase, also called NADH-quinone reductase, NDH-1, or complex I. No specific role is attached to the subunit but as a whole, the protein is involved in aerobic respiration and photosynthesis via $\mathrm{NADH}$-quinone reductase, capable of oxidizing $\mathrm{NADH}$, reducing quinone, and pumping proton [24]. By binding quinone, a peroxide source, it affects the production of ROS. The defective chloroplast $\mathrm{NDH}$ in rice mutant shows that the plant growth and PsII yield were slightly impaired in low light and is essential in improving oxidative stress in variable light $[25,26]$. Other studies identified more NDH subunits in plants and have reported their functions in energy metabolism in the plastid [27]. The other redox-related 
protein, TRX-m $\mathrm{m}_{3}$, regulates redox homeostasis, and this role was also found to relate to the cellular transport regulating functions. TRX-m $\mathrm{m}_{3}$ reduces plastid glucose-6-phosphate dehydrogenase (G6PDH), one of the enzymes in the oxidative pentose phosphate pathway [28]. The reaction then allows for NADPH regeneration, which is essential in preventing oxidative stress.

Based on the roles of these redox-related proteins, a few interpretations can be made with regard to the activities in the sampled sago palm. The earlier discussion on APX identifies it as a peroxide-reducing protein, with peroxide as a type of ROS and an important messenger in the signaling mechanism. The high transcript levels of APX and SDR in the T sample show an active signaling mechanism occurring, possibly due to the stresses sensed by the palm. This active signaling possibly prevented further accumulation of ROS from affecting the sago palm growth and development. On the other hand, the APX may signify a higher respiration rate in the T palm, indicated by the possibly higher presence of peroxide. Likewise, the two proteins identified in the NT sample, TRX-m 3 and NADH-dehydrogenase subunit 2, were found to take part in the respiratory chain, but without the direct ROSbinding roles as seen with the APX. TRX- $\mathrm{m}_{3}$ is involved in a reaction that indirectly links it to redox-regulating roles. A list of the proteins linked to redox signaling and regulation is shown in Table 3.

\subsection{DETs with Roles in $\mathrm{Ca}^{2+}$ and $\mathrm{N}$ Signaling and Regulation}

Calcium and nitrogen are elements that are also involved in a plant's signaling system. ROS generated in the various metabolic and respiratory processes not only causes oxidative stress when accumulated but is also found to activate the Ca-permeable channel and K-permeable channel. In such conditions, a high concentration of free $\mathrm{Ca}^{2+}$ in the cytosols can be observed. The presence of $\mathrm{Ca}^{2+}$ in cytosols also influences the uptake of $\mathrm{Na}^{+}$and $\mathrm{K}^{+}$. Sodium $(\mathrm{Na})$ is an element that may be toxic with high levels in the cytosols. In the $\mathrm{K}, \mathrm{Na}$, and Ca network, it is found that a low $\mathrm{K}^{+}$level or a high $\mathrm{Na}^{+}$concentration can trigger a change in the $\mathrm{Ca}^{2+}$ level [29]. The $\mathrm{Ca}^{2+}$ sensors respond by regulating the uptake and distribution of $\mathrm{K}^{+}$and $\mathrm{Na}^{+}$. This illustrates the interrelatedness and dependency of the various networks in the plant system.

Proteins involved in the regulative processes involving calcium as the secondary messenger were found with higher abundance in NT samples. DETs encoding calmodulin and $\mathrm{Ca}^{2+} / \mathrm{Na}^{+}$antiporter sodium/calcium exchanger (NCX) were expressed with intensity differences as high as $123 \%$ and $47 \%$, respectively. In Ca-signaling, a stimulus produces a pattern of spikes in $\mathrm{Ca}^{2+}$ concentration, with differing frequency and amplitude. This is interpreted by $\mathrm{Ca}^{2+}$ sensors such as calmodulin. The complex formed between $\mathrm{Ca}^{2+}$ and the $\mathrm{Ca}^{2+}$ sensor binds and changes the conformation and activity of the target protein and may also regulate gene expression, indirectly triggering cell response [30]. In plants, Magnesium Proton Exchangers (MHX), which is the homolog of NCX, functions in regulating the $\mathrm{Zn}^{2+}$ and $\mathrm{Mg}^{2+}$ level with $\mathrm{H}^{+}$gradient as the driving force [31]. A study on sago palm in peat soil found these two micronutrients to be of importance to the palm's productivity [40]. $\mathrm{Mg}^{2+}$ is required for starch synthesis processes. The deficiency of $\mathrm{Mg}^{2+}$ was found to inhibit carbohydrate transport, whereas, in excess, it inhibited photosynthesis. Zinc deficiency meanwhile will result in enhanced RNA degradation and reduced rate of protein synthesis, whereas, in toxic levels, photosynthesis and root growth are reduced.

Transcriptional regulator asparagine synthetase $\mathrm{C}(\mathrm{AsnC})$ and nonsymbiotic hemoglobin $1(\mathrm{nsHb})$ are two proteins involved in regulating nitrogen-related reactions. The DET encoding for AsnC was found with higher abundance in the T sample (56\%), whereas the DET encoding for nsHb was only expressed in the NT sample. AsnC is a member of the leucine-responsive regulatory protein family. This transcriptional regulator activates the protein asparagine synthetase $\mathrm{A}$ (AsnA), which catalyzes the formation of asparagine from ammonia and aspartic acid, in the presence of Adenosine Triphosphate (ATP) [35]. The involvement of AsnC in the formation of asparagine, indirectly optimizing the utilization of nitrogen in plants [36], can be seen as a mechanism being expressed during nitrosative stress. Asparagine Synthetase (ASN) genes are readily present in plants

Table 3: List of genes with redox sensor and regulator-related functions.

\begin{tabular}{|c|c|c|c|c|}
\hline Sample label & Identity matches & $\begin{array}{l}\text { DET intensity } \\
\text { difference }(\%)\end{array}$ & Roles & References \\
\hline $8 \mathrm{~T} 1$ & Cytosolic APX & 81 & $\begin{array}{c}\text { Reduce peroxide } \\
\text { Respond to combination stress }\end{array}$ & $\begin{array}{l}\text { Akbudak et al }[20] \text {; } \\
\text { Wu and Wang [21] }\end{array}$ \\
\hline $11 \mathrm{~T} 51$ & $\mathrm{Crp} /$ Fnr family transcriptional regulator & 49 & $\begin{array}{l}\text { Redox sensing interpret stimuli and } \\
\text { activate appropriate responses }\end{array}$ & $\begin{array}{l}\text { Soberón-Chávez et al. } \\
\text { [18]; Kim et al. [19] }\end{array}$ \\
\hline $13 \mathrm{~T} 350$ & Short-chain dehydrogenase/reductase; SDR & 47 & $\begin{array}{l}\text { Redox sensing related to regulation } \\
\text { of various metabolic reactions, } \\
\text { transcription, and signaling roles } \\
\text { involve NADPH binding }\end{array}$ & Chen et al. [32] \\
\hline $15 \mathrm{t} 51$ & Thioredoxin $\mathrm{m}_{3}$ & 116 & $\begin{array}{l}\text { Reduce G6PDH in the oxidative } \\
\text { pentose phosphate pathway } \\
\text { involved in preventing oxidative } \\
\text { stress by allowing NADPH } \\
\text { regeneration }\end{array}$ & $\begin{array}{l}\text { Benitez-Alfonso et al. } \\
\text { [33]; González et al. [34]; } \\
\text { Yoshida et al. [35] }\end{array}$ \\
\hline $15 \mathrm{t} 51$ & NADH-dehydrogenase subunit 2 & 116 & $\begin{array}{l}\text { A subunit making up the NADH- } \\
\text { quinone reductase complex is } \\
\text { involved in energy metabolism and } \\
\text { reduces quinone }\end{array}$ & $\begin{array}{l}\text { Kerscher et al. [24]; } \\
\text { Strand et al. [24] }\end{array}$ \\
\hline
\end{tabular}


Table 4: List of genes with $\mathrm{Ca}^{2+}$ and $\mathrm{N}$ sensor and regulatory-related functions.

\begin{tabular}{|c|c|c|c|c|}
\hline Sample label & Identity matches & $\begin{array}{l}\text { DET intensity } \\
\text { difference (\%) }\end{array}$ & Roles & References \\
\hline $4 \mathrm{t} 3$ & $\mathrm{Ca}^{2+} / \mathrm{Na}^{+}$antiporter & 47 & $\begin{array}{l}\text { The plant homolog MHX functions } \\
\text { in the transport and regulation of } \\
\mathrm{Mg}^{2+} \text { and } \mathrm{Zn}^{2+} \text { levels in cells }\end{array}$ & Taneja et al. [31] \\
\hline $4 \mathrm{t} 4$ & Calmodulin-like protein & 123 & $\begin{array}{l}\text { Calcium sensor interpret stimuli and } \\
\text { induce respective responses, usually } \\
\text { related to osmotic stress }\end{array}$ & Kim et al. [30] \\
\hline 5.3 and 5.7 & $\begin{array}{l}\text { Transcriptional regulator, AsnC } \\
\text { family }\end{array}$ & 65 & $\begin{array}{l}\text { Activate AsnA involved in the } \\
\text { formation of asparagine }\end{array}$ & $\begin{array}{l}\text { Kambhampati et al. [35]; } \\
\text { Gaufichon et al. }[36]\end{array}$ \\
\hline $14 \mathrm{t} 453$ & $\mathrm{nsHb} 1$ & Only present in NT & $\begin{array}{c}\text { Involved in NO metabolism and } \\
\text { stress tolerance regulate nitrogen } \\
\text { uptake and ATP level during limited } \\
\text { oxygen supply }\end{array}$ & $\begin{array}{c}\text { Ma et al. [37]; Berger et } \\
\text { al. [38] }\end{array}$ \\
\hline $14 \mathrm{t} 453$ & $\begin{array}{c}\text { Quinoprotein amine } \\
\text { dehydrogenase; beta chain-like } \\
\text { protein }\end{array}$ & Only present in NT & $\begin{array}{l}\text { Catalyse oxidative deamination } \\
\text { process of primary amines }\end{array}$ & Schmitt et al. [39] \\
\hline
\end{tabular}

and are differentially expressed throughout plant development. The roles of the gene products are not limited to recycling nitrogen in the vegetative organs [36]. The other protein, $\mathrm{nsHb}$, is one of the three types of $\mathrm{Hb}$ found in plants. These proteins that are expressed in osmotic stress, nutrient deprivation, nitric oxide exposure, and even rhizobial infection act together with APX [37]. The nsHb is classified into class 1 and class 2 based on the oxygen affinity, and of these two, $\mathrm{nsHb}-1$ is more studied. Findings for nsHb-1 include its functions in nitrogen oxide (NO)-related metabolic processes and its expression during stress tolerance [38]. When under an oxygen-limited environment, the reaction between $\mathrm{nsHb}$ and $\mathrm{NO}$ helps regulate ATP level for mitochondrial electron transport processes [37]. By the presence of these proteins, it can be deduced that both T and NT sago palm were responding to nitrogen limitation.

A comparison of the discussed proteins revealed the $\mathrm{T}$ sample as having efficient nitrogen utilization through asparagine formation by AsnC and the NT sample as having active nitrogen uptake through $\mathrm{nsHb}$. The transcript in the NT sample also showed a sensor and antiporter functioning to ensure the proper level of $\mathrm{Ca}^{2+}$ and possibly $\mathrm{Mg}^{2+}$ and $\mathrm{Zn}^{2+}$ in the palm. Based on the above protein functions, NT palm can be portrayed as nutritionally challenged, which could be attributed to its growth condition in deep peat soil. A list of the proteins linked to $\mathrm{Ca}^{2+}$ and $\mathrm{N}$ signaling and regulation is compiled in the following Table 4.

\subsection{Transport-Related Proteins}

The functions of the transport-related proteins were mostly identified to transport various substrates through membranes. The transcript encoding for ER-Golgi Soluble N-ethylmale-imidesensitive factor-attachment Protein Receptors (SNARE) complex subunit was found more abundant in the NT sample (127\%) where the transcript for sorting nexin (SNX) is more in the T sample (65\%). The endoplasmic reticulum-Golgi(ER-G) SNARE complex is involved in the transport between the ER and the G apparatus, functioning as coating proteins and facilitating the membrane fusion between the two organelles [23,41]. Meanwhile, the trafficking role of SNX is suggested to occur between endosomes and vacuole [42]. As a family of cellular trafficking proteins, SNX has general roles in protein-protein interaction via membrane association and possible roles in protein sorting $[43,44]$. It was initially presumed that since vesicular trafficking and intercellular transport mechanism are a natural process in all cells, their effects on this differential expression study in the NT and T samples would be negligible. Phan et al. [42], however, showed that these proteins are important in ensuring that the plant cellular trafficking system is regulated. In their study, the overexpression of the lipidbinding SNX in Arabidopsis was shown to result in an enlarged endosome formation, restricting the trafficking to vacuoles.

Another protein involved in regulating the plant trafficking system is the previously discussed TRX-m ${ }_{3}$, also shown in the NT sample. In the extension of its role in redox homeostasis, TRX-m $\mathrm{m}_{3}$ was described to be responsible for regulating symplastic trafficking [45]. By linking ROS production with callose deposition, TRX-m $\mathrm{m}_{3}$ is suggested to regulate the plasmodesmata permeability and thus, responsible for regulating cellular signal and transport. The importance of this role is supported by the study of stunted growth and the effect of arrested symplastic trafficking [45]. The effect of redox homeostasis in carbon partitioning or callose production is also thought to affect carbon storage and hence the starch production [46].

Other DETs found involved in intracellular transport functions encode for peptide-2 ATP-binding cassette $(\mathrm{ABC})$ transporter and glucosyltransferase 2 . The transcript for peptide- $2 \mathrm{ABC}$ transporter was comparably abundant in the NT sample (45\%), whereas it was glucosyltransferase 2 in the T sample $(80 \%)$. ABC or ATP-binding cassette transporter is a protein that functions to transport various substrates across membranes, using the energy of adenosine triphosphate or ATP [47]. Based on the protein's annotation, the function is described to involve peptide. Glucosyltransferase 2 is part of the glycosyltransferase (GT) family. While the GT family is identified with various functions to include signaling, storage, and biosynthesis [48], the role for the transcript isolated in this study was identified to involve the transfer of glucose.

Also, more abundant in the $\mathrm{T}$ sample were transcripts encoding for inorganic phosphate transporter 3 (PHT3) and cobalt transport protein $(\mathrm{CbiO})$. Their band intensities in the $\mathrm{T}$ sample were higher 
by $49 \%$ and $35 \%$, respectively. PHT3 is a protein that assists in the transport of inorganic phosphate. Under its family classification, its function is localized in mitochondria, mobilizing the mineral across the inner membrane of the organelle [49]. As for the cobalt transport protein, $\mathrm{CbiO}$ is one of the four components making up the protein, which include two transmembrane components, a membrane-bound component, and an ATP-binding protein [51]. It is identified as the ABC-type cobalt transport protein, which facilitates the cobalt ion uptake. As with the peptide- $2 \mathrm{ABC}$ transporter, the $\mathrm{CbiO}$ is the component that enables the trafficking function of the transporter protein. Phosphate and cobalt are both essential minerals required in plant metabolic pathways [51]. Inorganic phosphate, in particular, is one of the components involved in forming ATP. Therefore, the functionality of PHT3 is important for energy production and possibly for the functionality of the ABC-related proteins.

The above proteins were described to have transporting roles, with involvement in other aspects of the plant system. Other than the SNX, other proteins in the T sample are found to have their specific cargo such as peptides to glucose. The proteins PHT3 and $\mathrm{CbiO}$ were involved in roles that signify the elements phosphate and cobalt as being actively processed in the T sample. In the NT sample, the proteins were believed to be involved in regulating the trafficking system in the cell and tissue to ensure that protein interaction and the various signaling occur. The higher expression of ER-Golgi SNARE and TRX-m $\mathrm{m}_{3}$ in NT may be related to the other role of TRX-m $\mathrm{m}_{3}$, as discussed earlier. Table 5 shows the compilation of proteins discussed in this section.

\subsection{Biosynthesis-Related and Other Proteins}

The protein products described in this section were involved in the mechanisms such as plant defense, redox regulation, and cell regulation. In the plant defense mechanisms, the plant must first detect and recognize the threat before it can induce the appropriate responses. Cellular membrane and cell wall both act as the primary defense against invasion while sensing for threats and being involved in general signaling. The structures that signal invasion and trigger plant defenses include the lipopolysaccharide (LPS) and peptidoglycan, which are of bacterial origin. In this study, enzyme functioning in the biosynthetic pathway for LPS was detected, with the DET encoding it higher by $36 \%$ in intensity value in the $\mathrm{T}$ sample. The transcript identity, $\mathrm{O}$-antigen ligase, functions by adding $\mathrm{O}$-antigen to the glucose group [52]. In the peptidoglycan synthesis pathway, UDP-N-acetylmuramoyl-Lalanyl-D-glutamate-lysine ligase or MurE plays a role in the transfer of amino acids [53]. The transcript encoding for the enzyme was found to be more abundant in NT samples (116\%). The previous study found the enzyme expressed in leaves and flowers, specifically in plastids, and suggested MurE being involved in the proper development of the chloroplast [54].

Other proteins involved in plant defense are beta-glucosidase and mitogen-activated protein kinase 4 (MAPK4). Detection of potential threat signals and induces the defenses in the form of chemicals and hormones. Portraying the characteristics of family 1 glycoside hydrolases, beta-glucosidase is found to influence the formation of intermediates in cell wall lignifications [56]. It is also stored in an inactive glycosylated form, released when the cell wall is ruptured, activating the chemicals defenses (phytoanticipins) and phytohormones of the plants [57]. The DET encoding for beta-glucosidase was found comparatively abundant in the T sample (16\%). The DET encoding for the other protein, MAPK4, was more abundant in the NT sample (529\%). The roles of MAPK4 include repressing systemic acquired resistance (SAR) and inducing jasmonic acid (JA)-responsive gene expression [58]. The transcript abundance presents speculation of the high occurrence of signaling and JA-responsive gene expression. Due to the opposing roles of MAPK4 towards SA- and JA-dependent defense pathway, it is indeterminate whether its presence in the NT sample is defense-related.

The following proteins, membrane-associated zinc metallopeptidase and riboflavin synthase, are proteins with roles in energy metabolism. The DETs encoding for these proteins are from the NT sample, with higher band intensity of $123 \%$ and $47 \%$, respectively. The

Table 5: List of genes with transport-related functions.

\begin{tabular}{|c|c|c|c|c|}
\hline Sample label & Identity matches & $\begin{array}{l}\text { DET intensity } \\
\text { difference (\%) }\end{array}$ & Roles & References \\
\hline $1 \mathrm{~T} 31,3,4$ & Cobalt transport protein, $\mathrm{CbiO}$ & 35 & Facilitate cobalt transport & Bao et al. [50] \\
\hline 5.3 and 5.7 & SNX & 65 & $\begin{array}{l}\text { Facilitate protein interaction via } \\
\text { membrane association possible roles } \\
\text { in protein sorting }\end{array}$ & $\begin{array}{c}\text { Phan et al. [42]; Brumbarova } \\
\text { and Ivanov [43] }\end{array}$ \\
\hline $8 \mathrm{~T} 1$ & Glucosyltransferase family 2 & 80 & Involved in the transfer of glucose & Zhou et al. [52] \\
\hline $11 \mathrm{t} 31$ & $\begin{array}{l}\text { ER-Golgi SNARE complex } \\
\text { subunit }\end{array}$ & 127 & $\begin{array}{l}\text { Vesicular transport via coat protein } \\
\text { facilitates membrane fusion involved } \\
\text { in signal transduction }\end{array}$ & $\begin{array}{c}\text { Moreau et al. [41]; Yang et al. } \\
\text { [23] }\end{array}$ \\
\hline $11 \mathrm{~T} 51$ & Inorganic PHT3 & 49 & $\begin{array}{l}\text { Mobilise phosphate within } \\
\text { mitochondria }\end{array}$ & Ukleja et al. [55] \\
\hline $15 \mathrm{t} 51$ & Thioredoxin $\mathrm{m}_{3}$ & 116 & $\begin{array}{l}\text { Regulate plasmodesmata permeability } \\
\text { for cellular signaling and transport }\end{array}$ & Calderón et al. [45] \\
\hline $19 \mathrm{~T} 5$ & $\begin{array}{c}\text { Peptide-2 ABC transporter; } \\
\text { ATP-binding/membrane-spanning } \\
\text { protein }\end{array}$ & 45 & Transport peptide across membranes & Lane et al. [47] \\
\hline
\end{tabular}


membrane-associated zinc metallopeptidase is suggested to have cleaving functions at the trans-membrane [59]. Several homologs of the metallopeptidase have been identified in Arabidopsis using the bioinformatics approach [60]. One of the many homologs is found to be involved in the site-2 protease (S2P) signaling cascade, with roles in regulating the chloroplast development [16]. Proper development of the thylakoid grana and lamellae and accumulation of chlorophyll is important for a functional chloroplast. As with an earlier mentioned protein, membrane-associated zinc metallopeptidase is expected to regulate against abnormal development of chloroplast. As for riboflavin synthase subunit alpha, its role in the formation of riboflavin $\left(\mathrm{B}_{2}\right)$ [61] showed that the transcript is expressed in many organisms. Riboflavin is important as flavocoenzymes in energy production. The enzyme is therefore located in the plastids, cytosols, and mitochondria [62].

In other biosynthetic roles, the glycerol kinase and Phosphotransferase System (PTS) system transcriptional activator are some proteins involved in the synthesis of glycerol and sugar. Both DETs are more abundant in $\mathrm{T}$ samples $(57 \%$ and $4 \%$, respectively) and partly function to regulate the cellular concentration of related substrates. Glycerol kinase is an enzyme involved in the biosynthesis of glycerol, triglyceride, and glycerophospholipids [63]. The protein product, glycerol, is a compound involved in metabolism and cell signaling, particularly in osmotic stress signaling. Glycerol helps maintain the water balance in cells and enhances resistance to osmotic stress $[64,65]$. Its other products appear to be involved in reactions related to energy metabolism and structure formation. A triglyceride is a form of energy reserve in plants, whereas glycerophospholipids make for a key component in the cell structure. PTS or phosphotransferase system transcriptional activator is one of the many enzymes which function to regulate sugar biosynthesis as a sensor and phosphorylating agent [66].

The following transcript identities were proteins without any similarity in functions or roles with each other. Deoxyhypusine synthase (DHS) was expressed to be $80 \%$ higher in the T sample. Its role in adding hypusine to eukaryotic translational initiator factor 5A (eIF-5A) precursor protein is imperative for activating the eIF-5A complex [67]. The eIF-5A has been identified in plants with differing functions among its isoforms, but the activation of the protein relies on DHS. Among the many roles of eIF-5A in plant growth and development, of particular interest are the roles of the isoforms in cell division and senescence [69]. The expression of DHS and an eIF-5A isoform was found to increase in senescing parts of a plant. While identifying this process as a stress tolerance mechanism, a study found that suppression of these proteins prevented senescence and caused plant growth can be severely stunted [70]. The observation provided a possible scenario explaining the stunted disposition of NT sago palm. Finally, isolated in the NT sample with a $127 \%$ higher intensity value is GntR transcriptional regulator. The protein was identified as a transaminase that functions in processes such as amino acid metabolism. Studies on this protein identified many other roles which are specific to bacteria but identified as a member of the

Table 6: List of genes with biosynthesis-related functions and other proteins.

\begin{tabular}{|c|c|c|c|c|}
\hline Sample label & Identity matches & $\begin{array}{l}\text { DET intensity } \\
\text { difference }(\%)\end{array}$ & Roles & References \\
\hline $4 \mathrm{t} 3$ & $\begin{array}{c}\text { Riboflavin synthase, subunit } \\
\text { alpha }\end{array}$ & 47 & Catalyze riboflavin synthesis & Hsieh and Waters [61], \\
\hline $4 \mathrm{t} 4$ & $\begin{array}{l}\text { Membrane-associated zinc } \\
\text { metallopeptidase }\end{array}$ & 123 & $\begin{array}{c}\text { Cleaving at trans-membrane involved } \\
\text { in S2P signaling cascade and } \\
\text { chloroplast regulation }\end{array}$ & Chen et al. [16], Adamiec et al. [59] \\
\hline $8 \mathrm{~T} 1$ & DHS & 80 & Activate eIF-5A protein & Zheng et al. [67] \\
\hline $9 \mathrm{t} 4$ & MAPK 4 & 529 & $\begin{array}{l}\text { Repress SAR regulate signaling } \\
\text { and expression of salicylic- and JA- } \\
\text { responsive genes }\end{array}$ & Andrási et al. [58] \\
\hline $11 \mathrm{t} 31$ & $\begin{array}{l}\text { Transcriptional regulator } \\
\text { GntR family with } \\
\text { aminotransferase domain }\end{array}$ & 127 & $\begin{array}{l}\text { Involved in transamination in amino } \\
\text { acid involved in the metabolism of } \\
\text { various compounds }\end{array}$ & Taw et al. [68] \\
\hline $14 \mathrm{~T} 28$ & Beta-glucosidase & 16 & $\begin{array}{l}\text { Involved in cell wall lignification } \\
\text { involved in defense mechanism }\end{array}$ & Singhania et al. [56]; Morant et al. [57] \\
\hline $14 \mathrm{~T} 351$ & O-Antigen ligase-like protein & 36 & $\begin{array}{l}\text { Add O-antigen to glucose group in the } \\
\text { LPS biosynthetic pathway }\end{array}$ & Erbs et al. [52] \\
\hline $15 \mathrm{~T} 1$ & $\begin{array}{l}\text { PTS system transcriptional } \\
\text { activator }\end{array}$ & 4 & $\begin{array}{l}\text { Function as a phosphorylating agent } \\
\text { regulate sugar biosynthesis }\end{array}$ & Saier Jr [66] \\
\hline $15 \mathrm{t} 51$ & $\begin{array}{l}\text { UDP-N-acetylmuramoyl-L- } \\
\text { alanyl-D-glutamate-lysine } \\
\text { ligase }\end{array}$ & 116 & $\begin{array}{l}\text { Transfer amino acid in peptidoglycan } \\
\text { synthesis involved in regulating } \\
\text { chloroplast synthesis }\end{array}$ & Sato and Takano [53]; Lin et al. [54] \\
\hline $17 \mathrm{~T} 1$ & Glycerol kinase & 57 & $\begin{array}{l}\text { Involved in the biosynthesis } \\
\text { of glycerol, triglyceride, and } \\
\text { glycerophospholipids }\end{array}$ & Singh et al. [64]; Zhao et al. [65] \\
\hline
\end{tabular}


MocR subfamily $[68,71]$, the protein may be involved in the synthesis and catabolism of various compounds such as rhizopine [72] and pyridoxal phosphate [73,74].

In a summary, the $\mathrm{T}$ sample has a higher expression of defenserelated and regulative proteins. Based on the earlier described roles of glycerol kinase and its products, it is presumed that the $\mathrm{T}$ sample had the advantage of enhanced tolerance towards osmotic stress and better water stability. The enzyme expressing plant defense and structure-forming roles is beta-glucosidase. The activation of eIF-5A via DHS in the T sample ensures the proper growth via mRNA metabolism and trafficking. On the contrary, its suppression enhances stress tolerance. The NT sample has a higher expression of proteins involved in energy metabolism. The synthesis of riboflavin supports the production of flavocoenzymes needed in the cellular respiration reaction, whereas zinc metallopeptidase and MurE ensure proper synthesis and regulation of the chloroplast. The higher transcript expression of the chloroplast-regulating proteins in NT does not necessarily enhance the energy-generating potential of the organelle in the plant. Rather, their expression may be in response to other circumstances which involve the chloroplast. MAPK4 is the only transcript in the NT sample with regulative roles in the signaling of plant-pathogen defense. The protein is similarly induced in other stress signaling pathways. The transcript identities discussed in this section are presented in Table 6 .

\section{CONCLUSION}

Identities of the annotated DETs mostly showed the gene expression to be regulated at varying levels. The proteins that were found expressed in only one sample are MAPK4 and proteins identified from sample 14t45, which include nsHb-1 and rasGTPase-activating proteins. Their transcripts were only found in NT. Other annotated ORFs for DETs with regulated expression showed identity matches (with $e$-value below 10) to protein with roles in redox regulation (APX; SDR), respiratory chain $\left(\mathrm{TRX}-\mathrm{m}_{3}\right)$, nutrient regulation (AsnC, calmodulin, GT, NCX, PHT, and peptide-ABC), trafficking mechanism (ER-G SNARE, SNX, and TRX-m ${ }_{3}$ ), and various biosynthetic and metabolic processes (beta-glucosidase, O-antigen ligase, and riboflavin synthase). Overall, the $\mathrm{T}$ sample has been shown to be more active in redox sensing and regulating, whereas NT showed active regulation of energy metabolism in respiratory chains and chloroplast development. The T sample showed signs of active regulation of nitrogen, phosphorus, and cobalt concentration. The defense activity in T sample came in the form of glycerol and against pathogens. The NT sample is also active in the regulation of $\mathrm{Ca}, \mathrm{Mg}$, and $\mathrm{Zn}$ concentration and regulation of traffic and transport-related roles in the cell and tissue. Based on these findings, there were clearly identified different levels of transcripts in two physiologically different sago palms, and these enzymes play a role in forming T and NT sago palm. The identities of the unannotated DETs and their contributory roles in the trunk formation or growth of sago palm remain open for future studies.

\section{ACKNOWLEDGEMENTS}

The authors would like to acknowledge Universiti Malaysia Sarawak and Sarawak State Government for support through
Tun Openg Research Chair Grant F07/TOC/1743/2018 and ORC/23/1229/2015(10). The authors also thank Datu Sajeli bin Kipli, former General Manager of Land Custody and Development Authority (Pelita), and Pelita Mukah staff for access to the Pelita Mukah Sebakong Sago Plantation, for the sampling.

\section{AUTHOR CONTRIBUTIONS}

All authors made substantial contributions to conception and design, acquisition of data, or analysis and interpretation of data; took part in drafting the article or revising it critically for important intellectual content; agreed to submit to the current journal; gave final approval of the version to be published; and agree to be accountable for all aspects of the work. All the authors are eligible to be an author as per the international committee of medical journal editors (ICMJE) requirements/guidelines.

\section{CONFLICTS OF INTEREST}

The authors report no financial or any other conflicts of interest in this work.

\section{ETHICAL APPROVALS}

This study does not involve experiments on animals or human subjects.

\section{PUBLISHER'S NOTE}

This journal remains neutral with regard to jurisdictional claims in published institutional affiliation.

\section{REFERENCES}

1. Flach M. Sago palm: Metroxylon sagu rottb.-Promoting the conservation and use of underutilized and neglected crops. 13. Bioversity International, Institute of Plant Genetics and Crop Plant Research, Gatersleben, Germany/International Plant Genetic Resources Institute, Rome, Italy, 1997.

2. Lim LWK, Chung HH, Hussain H, Bujang K. Sago palm (Metroxylon sagu Rottb.): now and beyond. Pertanika J Trop Agri Sci 2019;42: 435-51.

3. Achudan SN, Dos Mohamed AM, Abd Rashid RS, Mittis P. Yield and physicochemical properties of starch at different sago palm stages. Mater Today Proc 2020;31:122-6.

4. Ehara H, Toyoda Y, Johnson DV. Sago palm: multiple contributions to food security and sustainable livelihoods. Springer Nature, Basingstoke, UK, 2018.

5. Hussain H, Kamal MM, Al-Obaidi JR, Hamdin NE, Ngaini Z, MohdYusuf Y. Proteomics of sago palm towards identifying contributory proteins in stress-tolerant cultivar. Protein J 2020;39:62-72.

6. Songan P, Noweg GT, Harun WSW, Mohamad M. Sustainable livelihood of peatland dwellers in the Mukah watershed, Sarawak, Malaysia. In International symposium and workshop on tropical peatland, Yogyakarta, Indonesia, pp 171-6, 2007.

7. Apun K, Lihan S, Wong M, Bilung L. Microbiological characteristics of trunking and non-trunking sago palm peat soil: programme and abstract. In 1st ASEAN Sago Symposium 2009: Current Trend and Development in Sago Research, Sarawak, Malaysia, pp 29-30, 2009.

8. Sim S, Wasli M, Yong C, Howell P, Jumin C, Safie N, et al. Assessment of the humification degree of peat soil under sago (Metroxylon sagu) cultivation based on fourier transform infrared (FTIR) and ultravioletvisible (UV-Vis) spectroscopic characteristics. Mires Peat 2017;19:1-0. 
9. Hussain H, Yan WJ, Ngaini Z, Julaihi N, Tommy R, Bhawani SA. Differential metabolites markers from trunking and stressed nontrunking sago palm (Metroxylon sagu Rottb.). Curr Chem Biol $2020 ; 14: 262-78$.

10. Edward AS, Hussain H. Differential expression gene profiling of trunking and non-trunking sago palm. In: Proceedings of the 2nd Biotechnology Colloquium 2009, Department of Molecular Biology, Faculty of Resource Science and Technology, UNIMAS, Sarawak, Malaysia, 2009.

11. Baena-González E, Sheen J. Convergent energy and stress signaling. Trends Plant Sci 2008;13:474-82.

12. Lim LWK, Chung HH, Hussain H. Complete chloroplast genome sequencing of sago palm (Metroxylon sagu Rottb.): molecular structures, comparative analysis and evolutionary significance. Gene Rep 2020;19:100662.

13. Hwang IT, Kim YJ, Kim SH, Kwak CI, Gu YY, Chun JY. Annealing control primer system for improving specificity of PCR amplification. Biotech 2003;35:1180-4.

14. Schneider CA, Rasband WS, Eliceiri KW. NIH image to ImageJ: 25 years of image analysis. Nat Methods 2012;9:671-5.

15. Thompson JD, Higgins DG, Gibson TJ. Clustal W: improving the sensitivity of progressive multiple sequence alignment through sequence weighting, position-specific gap penalties and weight matrix choice. Nucleic Acids Res 1994;22:4673-80.

16. Chen G, Zhang X. New insights into S2P signaling cascades: regulation, variation, and conservation. Protein Sci 2010;19:2015-30.

17. Okamoto S, Yu F, Harada H, Okajima T, Hattan Ji, Misawa N, et al. A short-chain dehydrogenase involved in terpene metabolism from Zingiber zerumbet. FEBS J 2011;278:2892-900.

18. Soberón-Chávez G, Alcaraz LD, Morales E, Ponce-Soto GY, ServínGonzález L. The transcriptional regulators of the CRP family regulate different essential bacterial functions and can be inherited vertically and horizontally. Front Microbiol 2017;8:959.

19. Kim J, Kwon YS, Bae DW, Kwak YS. Proteomic reference map and comparative analysis between streptomyces griseus S4-7 and wbiE2 transcription factor-mutant strain. Plant Pathol J 2020;36:185.

20. Akbudak MA, Filiz E, Vatansever R, Kontbay K. Genome-wide identification and expression profiling of ascorbate peroxidase (APX) and glutathione peroxidase (GPX) genes under drought stress in Sorghum (Sorghum bicolor L.). J Plant Growth Regul 2018;37: 925-36.

21. Wu B, Wang B. Comparative analysis of ascorbate peroxidases (APXs) from selected plants with a special focus on Oryza sativa employing public databases. PLoS One 2019;14:e0226543.

22. Anjum NA, Gill SS, Gill R, Hasanuzzaman M, Duarte AC, Pereira E, et al. Metal/metalloid stress tolerance in plants: role of ascorbate, its redox couple, and associated enzymes. Protoplasma 2014;251:126583 .

23. Yang X, Liao CY, Tang J, Bassham DC. Overexpression of trans-Golgi network t-SNARE s rescues vacuolar trafficking and TGN morphology defects in a putative tethering factor mutant. Plant J 2019;99:703-16.

24. Kerscher S, Dröse S, Zickermann V, Brandt U. The three families of respiratory NADH dehydrogenases. Bioenerg 2007;45:185-222.

25. Yamori W, Makino A, Shikanai T. A physiological role of cyclic electron transport around photosystem $\mathrm{i}$ in sustaining photosynthesis under fluctuating light in rice. Sci Rep 2016;6:20147.

26. Yamori W, Shikanai T, Makino A. Photosystem i cyclic electron flow via chloroplast nadh dehydrogenase-like complex performs a physiological role for photosynthesis at low light. Sci Rep 2015;5:13908.

27. Strand DD, D'Andrea L, Bock R. The plastid NAD (P) H dehydrogenase-like complex: structure, function and evolutionary dynamics. Biochem J 2019;476:2743-56.

28. González D, Álamos P, Rivero M, Orellana O, Norambuena J, Chávez $\mathrm{R}$, et al. Deciphering the role of multiple thioredoxin fold proteins of Leptospirillum sp. in oxidative stress tolerance. Int J Mol Sci 2020;21:1880.

29. Luan S, Lan W, Lee SC. Potassium nutrition, sodium toxicity, and calcium signaling: connections through the CBL-CIPK network. Curr Opin Plant Biol 2009;12:339-46.

30. Kim MC, Chung WS, Yun DJ, Cho MJ. Calcium and calmodulinmediated regulation of gene expression in plants. Mol Plant 2009;2:13-21.

31. Taneja M, Tyagi S, Sharma S, Upadhyay SK. Ca2+/cation antiporters $(\mathrm{CaCA})$ : identification, characterization and expression profiling in bread wheat (Triticum aestivum L.). Front Plant Sci 2016;7:1775.

32. Chen H, Yue Y, Yu R, Fan Y. A Hedychium coronarium short chain alcohol dehydrogenase is a player in allo-ocimene biosynthesis. Plant Mol Biol 2019;101:297-313.

33. Benitez-Alfonso Y, Cilia M, San Roman A, Thomas C, Maule A, Hearn S, et al. Control of Arabidopsis meristem development by thioredoxin-dependent regulation of intercellular transport. Proc Nat Acad Sci 2009;106:3615-20.

34. Yoshida K, Uchikoshi E, Hara S, Hisabori T. Thioredoxin-like2/2Cys peroxiredoxin redox cascade acts as oxidative activator of glucose-6-phosphate dehydrogenase in chloroplasts. Biochem J 2019;476:1781-90.

35. Kambhampati S, Ajewole E, Marsolais F. Advances in asparagine metabolism. In: Cánovas F, Lüttge U, Matyssek R (eds). Progress in Botany, Springer, Cham, Vietnam, pp 49-74, 2017, vol 79.

36. Gaufichon L, Reisdorf-Cren M, Rothstein SJ, Chardon F, Suzuki A. Biological functions of asparagine synthetase in plants. Plant Sci 2010;179:141-53.

37. Ma Z, Marsolais F, Bykova NV, Igamberdiev AU. Nitric oxide and reactive oxygen species mediate metabolic changes in barley seed embryo during germination. Front Plant Sci 2016;7:138.

38. Berger A, Boscari A, Frendo P, Brouquisse R. Nitric oxide signaling, metabolism and toxicity in nitrogen-fixing symbiosis. J Exp Bot 2019;70:4505-20.

39. Schmitt G, Saft M, Arndt F, Kahnt J, Heider J. Two different quinohemoprotein amine dehydrogenases initiate anaerobic degradation of aromatic amines in Aromatoleum aromaticum EbN1. J Bacteriol 2019;201:e0281-19.

40. Matsumoto M, Osaki M, Nuyim T, Jongskul A, Eam-on P, Kitaya Y, et al. Nutritional characteristics of sago palm and oil palm in tropical peat soil. J Plant Nutr 1998;21:1819-41.

41. Moreau P, Brandizzi F, Hanton S, Chatre L, Melser S, Hawes C, et al. The plant ER-Golgi interface: a highly structured and dynamic membrane complex. J Exp Bot 2007;58:49-64.

42. Phan NQ, Kim SJ, Bassham DC. Overexpression of Arabidopsis sorting nexin AtSNX2b inhibits endocytic trafficking to the vacuole. Mol Plant 2008;1:961-76.

43. Brumbarova T, Ivanov R. Differential gene expression and protein phosphorylation as factors regulating the state of the Arabidopsis SNX1 protein complexes in response to environmental stimuli. Front Plant Sci 2016;7:1456.

44. Jaillais Y, Fobis-Loisy I, Miège C, Gaude T. Evidence for a sorting endosome in Arabidopsis root cells. Plant J 2008;53:237-47.

45. Calderón A, Sevilla F, Jiménez A. Redox protein thioredoxins: function under salinity, drought and extreme temperature conditions. In: Gupta D, Palma J, Corpas F (eds). Antioxidants and Antioxidant Enzymes in Higher Plants, Springer, New York, NY, pp 123-62, 2018

46. Ning P, Yang L, Li C, Fritschi FB. Post-silking carbon partitioning under nitrogen deficiency revealed sink limitation of grain yield in maize. J Exp Bot 2018;69:1707-19.

47. Lane TS, Rempe CS, Davitt J, Staton ME, Peng Y, Soltis DE, et al. Diversity of $\mathrm{ABC}$ transporter genes across the plant kingdom and their potential utility in biotechnology. BMC Biotechnol 2016;16:1-0. 
48. Zhou P, Pu T, Gui C, Zhang X, Gong L. Transcriptome analysis reveals biosynthesis of important bioactive constituents and mechanism of stem formation of Dendrobium huoshanense. Scie Rep 2020;10:1-1.

49. Liu F, Chang XJ, Ye Y, Xie WB, Wu P, Lian XM. Comprehensive sequence and whole-life-cycle expression profile analysis of the phosphate transporter gene family in rice. Mol Plant 2011;4:1105-22.

50. Bao Z, Qi X, Hong S, Xu K, He F, Zhang M, et al. Structure and mechanism of a group-I cobalt energy coupling factor transporter. Cell Res 2017;27:675-87.

51. Akeel A, Jahan A. Role of cobalt in plants: its stress and alleviation. In: Naeem M, Ansari A, Gill S (eds). Contaminants in Agriculture, Springer, New York, NY, pp 339-57, 2020.

52. Erbs G, Molinaro A, Dow J, Newman MA. Lipopolysaccharides and plant innate immunity. In: Wang X, Quinn P (eds). Endotoxins: Structure, Function and Recognition, Springer, New York, NY, pp 387-403, 2010

53. Sato N, Takano H. Diverse origins of enzymes involved in the biosynthesis of chloroplast peptidoglycan. J Plant Res 2017;130:635-45.

54. Lin X, Li N, Kudo H, Zhang Z, Li J, Wang L, et al. Genes sufficient for synthesizing peptidoglycan are retained in gymnosperm genomes, and MurE from Larix gmelinii can rescue the albino phenotype of Arabidopsis MurE mutation. Plant Cell Physiol 2017;58:587-97.

55. Ukleja M, Valpuesta JM, Dziembowski A, Cuellar J. Beyond the known functions of the CCR4-NOT complex in gene expression regulatory mechanisms: new structural insights to unravel CCR4NOT mRNA processing machinery. Bioessays 2016;38:1048-58.

56. Singhania RR, Patel AK, Pandey A, Ganansounou E. Genetic modification: a tool for enhancing beta-glucosidase production for biofuel application. Bioresour Technol 2017;245:1352-61.

57. Morant AV, Jørgensen K, Jørgensen C, Paquette SM, Sánchez-Pérez $\mathrm{R}$, Møller BL, et al. $\beta$-Glucosidases as detonators of plant chemical defense. Phytochem 2008;69:1795-813.

58. Andrási N, Rigó G, Zsigmond L, Pérez-Salamó I, Papdi C, Klement $\mathrm{E}$, et al. The mitogen-activated protein kinase 4-phosphorylated heat shock factor A4A regulates responses to combined salt and heat stresses. J Exp Bot 2019;70:4903-18.

59. Adamiec M, Ciesielska M, Zalaś P, Luciński R. Arabidopsis thaliana intramembrane proteases. Acta Physiol Plant 2017;39:1-7.

60. Kinch LN, Ginalski K, Grishin NV. Site-2 protease regulated intramembrane proteolysis: sequence homologs suggest an ancient signaling cascade. Protein Sci 2006;15:84-93.

61. Hsieh EJ, Waters BM. Alkaline stress and iron deficiency regulate iron uptake and riboflavin synthesis gene expression differently in root and leaf tissue: implications for iron deficiency chlorosis. J Exp Bot 2016;67:5671-85

62. Roje S. Vitamin B biosynthesis in plants. Phytochem 2007;68:1904-21.

63. Hohmann S. Osmotic stress signaling and osmoadaptation in yeasts. Microbiol Mol Biol Rev 2002;66:300-72.

64. Singh V, Singh PK, Siddiqui A, Singh S, Banday ZZ, Nandi AK. Over-expression of Arabidopsis thaliana SFD1/GLY1, the gene encoding plastid localized glycerol-3-phosphate dehydrogenase, increases plastidic lipid content in transgenic rice plants. J Plant Res 2016;129:285-93.
65. Zhao Y, Li X, Wang F, Zhao X, Gao Y, Zhao C, et al. Glycerol-3phosphate dehydrogenase (GPDH) gene family in Zea mays L.: identification, subcellular localization, and transcriptional responses to abiotic stresses. PloS One 2018;13:e0200357.

66. Saier Jr MH. The bacterial phosphotransferase system: new frontiers 50 years after its discovery. J Mol Microbiol Biotechnol 2015;25:73-8.

67. Zheng T, Zang L, Dai L, Yang C, Qu G. Two novel eukaryotic translation initiation factor $5 \mathrm{~A}$ genes from Populus simonii $\times$ P. nigra confer tolerance to abiotic stresses in Saccharomyces cerevisiae. J For Res 2017;28:453-63.

68. Taw MN, Lee HI, Lee SH, Chang WS. Characterization of MocR, a GntR-like transcriptional regulator, in Bradyrhizobium japonicum: its impact on motility, biofilm formation, and soybean nodulation. J Microbiol 2015;53:518-25.

69. Wang TW, Lu L, Wang D, Thompson JE. Isolation and characterization of senescence-induced cDNAs encoding deoxyhypusine synthase and eucaryotic translation initiation factor $5 \mathrm{~A}$ from tomato. J Biol Chem 2001;276:17541-9.

70. Thompson JE, Hopkins MT, Taylor C, Wang TW. Regulation of senescence by eukaryotic translation initiation factor 5A: implications for plant growth and development. Trends Plant Sci 2004;9:174-9.

71. Rigali S, Derouaux A, Giannotta F, Dusart J. Subdivision of the helixturn-helix GntR family of bacterial regulators in the FadR, HutC, MocR, and YtrA subfamilies. J Biol Chem 2002;277:12507-15.

72. Geddes BA, Paramasivan P, Joffrin A, Thompson AL, Christensen $\mathrm{K}$, Jorrin $\mathrm{B}$, et al. Engineering transkingdom signalling in plants to control gene expression in rhizosphere bacteria. Nature Commun 2019;10:1-1.

73. Magarvey N, He J, Aidoo K, Vining L. The pdx genetic marker adjacent to the chloramphenicol biosynthesis gene cluster in Streptomyces venezuelae ISP5230: functional characterization The GenBank accession number for the sequence reported in this paper is AF286159. Microbiol 2001;147:2103-12.

74. Nonaka S, Someya T, Zhou S, Takayama M, Nakamura K, Ezura H. An Agrobacterium tumefaciens strain with gamma-aminobutyric acid transaminase activity shows an enhanced genetic transformation ability in plants. Sci Rep 2017;7:1-1.

\section{How to cite this article:}

Hussain H, Edward-Atit AS, Julaihi N, Tommy R, Nisar M, Hamdan N, Ehara H. Identification of differentially expressed transcripts for trunk formation in sago palm using annealing control primer GeneFishing technique. J Appl Biol Biotech 2022; 10(02):21-34. 